\title{
TOURISM IS TOO DANGEROUS! PERCEIVED RISK AND THE SUBJECTIVE SAFETY OF TOURISM ACTIVITY IN THE ERA OF COVID-19
}

\author{
Tafadzwa MATIZA* \\ North-West University, Tourism Research in Economics, Environs and Society (TREES), Faculty of \\ Economic \& Management Sciences, Potchefstroom, South Africa, e-mail: matizata@hotmail.com/32552378@nwu.ac.za

\section{EImarie SLABBERT} \\ North-West University, North-West University, Tourism Research in Economics, Environs and Society (TREES), Faculty \\ of Economic \& Management Sciences, Private Bag X6001, Potchefstroom, South Africa, e-mail: elmarie.slabbert@nwu.ac.za
}

\begin{abstract}
Citation: Matiza, T., \& Slabbert, E. (2021). TOURISM IS TOO DANGEROUS! PERCEIVED RISK AND THE SUBJECTIVE SAFETY OF TOURISM ACTIVITY IN THE ERA OF COVID-19. GeoJournal of Tourism and Geosites, 36(2spl), 580-588. https://doi.org/10.30892/gtg.362spl04-686
\end{abstract}

\begin{abstract}
The COVID-19 pandemic has heightened the risk associated with tourism and induced a paradigm shift in tourist behaviour. The study explores the nexus between COVID-19 induced perceived risk the subjective safety associated with tourism activity. A cross-sectional deductive study was conducted. Data were generated from a respondent-driven snowball sample of 323 potential tourists from all over the world. The key findings indicate perceived physical, psychological and social COVID-19 pandemic induced risk negatively influenced the overall subjective safety associated with tourism activity. Moreover, further analysis indicated heterogeneity in the influence of the perceived risk on specific tourism activity. Tourism practitioners are provided with timely empirical evidence-based insights that contribute to a better understanding of tourists' evolving behaviour.
\end{abstract}

Key words: COVID-19, perceived risk, subjective safety, tourism activity, tourism value chain

$* * * * *$

\section{INTRODUCTION}

The exponential global spread of the novel coronavirus disease 2019 (COVID-19) is attributable to increased global mobility buoyed by tourism activity (Qiu et al., 2020). The COVID-19 pandemic is the first high-impact crisis event that is distinctly 'glocal' (Salazar, 2005), as a global pandemic with palpable idiosyncratic implications for each tourism destination in the world on a localised level (Perić et al., 2021). Therefore, to date, national governments have instituted many moratoriums on tourism activities, including international travel bans and the closure of tourism facilities (Chua et al., 2020; Matiza, 2020). The COVID-19 pandemic has exposed the global tourism industry's frailties and susceptibility to crises events such as health pandemics (Liu et al., 2013; Seabra et al., 2013). As the impact of consumerism and the importance of information symmetry becomes more evident in tourist's decision-making (Shaheer et al., 2019), tourists have also become more circumspect in their tourism consumption decisions. A study by Global Rescue and WTTC (2019) submits that tourism demand generally recovers 19.4 months after crises events associated with epidemics and outbreaks, signifying the need to better understand and predict tourist behaviour in the wake of crises events.

One key aspect to consider in post-crisis tourist decision-making in the era of COVID-19 is the impact of the pandemic on the psyche of tourists (Kock et al., 2020), more pertinently, perceived risk and how it influences the subjective safety of tourists in their consumptive decision-making. The present paper is premised on the notion that perceived risk triggers safety concerns (Liu et al., 2013). Consequently, safety concerns transcend travel intentions to influence the whole tourist decisionmaking process, including decisions associated with the mode, organisation and timing of travel, and destination choice (Karl and Schmude, 2017). While there has been a flurry of contemporary studies relating to the impact of the COVID-19 pandemic on tourism in general (Qiu et al., 2020; Wang et al., 2020) and more pertinently the cognitive and conative travel behaviour of tourists (Abraham et al., 2020; Bae and Chang, 2020; Chua et al., 2020; Li et al., 2020; Matiza, 2020; Perić et al., 2021), academic inquiry into the effect of the pandemic on the subjective safety associated with tourism activity is still minimal.

Moreover, incisive models of the influence of the perceived risk-subjective safety of tourism nexus in light of COVID-19 are currently absent from the literature; hence insights into the potentially multidimensional risk factors associated with the pandemic are yet to be fully explored. Despite the linkages within the tourism value chain, there is also scant comprehensive research into the impact of crises events on specific tourism-oriented services and products' subjective safety. The study aimed to explore the influence of COVID-19 induced risk perceptions on the subjective safety associated with tourism activity. The findings offer tourism practitioners critical and timely insights into the multidimensional nature of perceived risk associated with the COVID-19 pandemic, and whether risk perception influences tourists' views on how safe they perceive tourism to be in light of the pandemic. Our findings advance academic inquiry into the impact of the ongoing pandemic on tourist behaviour

\footnotetext{
* Corresponding author
} 
and enrich the extent of the literature on the role of risk perception in tourism by modelling the COVID-19 pandemic's multidimensional risk profile in relation to various tourism activities in the short-to-medium term.

\section{LITERATURE AND HYPOTHESES}

\section{Perceived risk and health crisis events in tourism}

Perceived risk within the tourism discourse is a subjective multidimensional construct that may be decomposed into 11 typologies, namely; equipment, financial, physical (health-related), psychological, satisfaction, social, time, crime, terror and political-oriented risk (Fuchs and Reichel, 2006; Matiza, 2020; Olya and Al-ansi, 2018; Perić et al., 2021; Reisinger and Mavondo, 2005; Qi et al., 2009). The established diversity in risk typology points to the potentially idiosyncratic nature and heterogeneous influence of risk perception in tourist behaviour (Seabra et al., 2013). For instance, Boksberger et al. (2007) found that financial, personal, functional and social risk influenced tourist decision-making concerning air travel, whereas An et al. (2010) associated air travel with physical, natural disaster, political and performance risk. Hence, perceived risk is a subjective construct that may be heterogeneous in influencing tourist decision-making and conative behaviour.

Perceived risk allied with health crises heightens tourist anxieties based on their perceived susceptibility to infection, as well as the perceived severity of the disease - often resulting in risk mitigation behaviour including the avoidance of specific destinations or particular tourism activities due to safety concerns (Liu et al., 2013; Neuburger and Egger, 2020; Perić et al., 2021; Sánchez-Cañizares et al., 2020). Previous flu-like virus outbreaks have had a discernible adverse effect on tourism's perceived safety and resulted in significant tourism demand decreases. For instance, there is empirical evidence of the declines in tourism demand in China (Dombey, 2003), Singapore (Henderson, 2003), and Taiwan (Wang, 2009) during the Severe Acute Respiratory Syndrome (SARS) outbreak. The subsequent H1N1 (swine flu) outbreak constrained both inbound and outbound tourism in the cases of tourism destinations such as Brunei (Haque and Haque, 2018), the United Kingdom (Page et al., 2012), and Japan (Kuo et al., 2008). Prior studies (Garg, 2013; Griffiths and Lau, 2009) have also established a correlation between health crises, heightened risk perceptions and the perceived safety of engaging in tourism activity during and postcrises. However, Perić et al., (2021) note that the COVID-19 pandemic 'transcends' the sheer scale and impact of all previous health crises that have impacted tourism. To this end, the growing body of knowledge (Bae and Chang, 2020; Neuburger and Egger, 2020; Wachyuni and Kusumaningrum, 2020) allied with the ongoing pandemic and tourism suggests that risk perceptions adversely affect and modify tourist behaviour, linking COVID-19 induced risk perceptions with avoidance behaviour and tourists' intentions to avoid travel and tourism activity (Bae and Chang, 2020; Neuburger and Egger, 2020; Wachyuni and Kusumaningrum, 2020). The COVID-19 pandemic presents a clear and present danger to tourists' health and well-being, possibly instigating risk-induced avoidance behaviour in the near future.

The present study explores risk perception associated with the COVID-19 pandemic in relation to the subjective safety of tourism activities in the near future (within the next year) based on a triad of dimensions, physical- [likelihood of the occurrence of danger, illness or injury]; psychological- [likelihood tourism activity will not reflect the tourist's self-image, not meet expectations, or create anxiety for their safety]; and social- [likelihood that tourism activity will negatively affect the opinion held of the tourist by the tourist's various social reference groups] risk dimensions (Deng and Ritchie, 2018; Fuchs and Reichel, 2006; Karl and Schmude, 2017; Khasawneh and Alfandi, 2019). The subjective safety of tourism activity in the near future integrates the broad spectrum of travel and tourism-related activity within the tourism value-chain to include; the scope of tourism [domestic and international travel]; activity choice [domestic and international tourist attractions]; mode of transport [air travel and private self-drive]; as well as interaction [group travel and tourist interaction], respectively. Beyond the palpable physical (health-related) risk associated with the COVID-19 pandemic, the psychological and social risk is the potential impact of additional perceived risk dimensions on tourism activity's subjective safety. Therefore, the following null hypotheses were tested,

$\mathrm{HO}_{1}$ : The perceived physical- $\left[\mathrm{HO}_{1 \mathrm{a}}\right]$, psychological- $\left[\mathrm{HO}_{1 \mathrm{~b}}\right]$, social- $\left[\mathrm{HO}_{1 \mathrm{c}}\right]$ risk associated with the COVID-19 pandemic does not significantly influence the subjective safety of tourism activity in the near future.

Perceived risk is a critical antecedent to tourist decisions (Reisinger and Mavondo, 2005). Prior studies have attributed that pervasiveness safety concerns associated with international travel to Thailand (Rittichainuwat and Chakraborty, 2009), the United Kingdom (Page et al., 2012) and African countries (Carter, 1998) to heightened perceived risk related to the SARS, H1N1 and HIV outbreaks, respectively. Domestic tourism demand in the United States of America (USA) was negatively affected by tourists' safety apprehensions and avoidance behaviour following the 2014 Ebola outbreak (Cahyanto et al., 2016). With this in mind, the following null hypotheses related to the COVID-19 pandemic and the subjective safety of international and domestic travel were tested.

$\mathrm{HO}_{2}$ : The subjective safety of international travel is not influenced by perceived physical- $\left[\mathrm{HO}_{2 \mathrm{a}}\right]$, psychological- $\left[\mathrm{HO}_{2 b}\right]$, social- $\left[\mathrm{HO}_{2 \mathrm{c}}\right]$ risk associated with the COVID-19 pandemic.

$\mathrm{HO}_{3}$ : The subjective safety of domestic travel is not influenced by perceived physical- $\left[\mathrm{HO}_{3 \mathrm{a}}\right]$, psychological- $\left[\mathrm{HO}_{3 \mathrm{~b}}\right]$, social$\left[\mathrm{HO}_{3 \mathrm{c}}\right]$ risk associated with the pandemic.

There is an established link between air travel and disease diffusion (Bowen and Laroe, 2006). Fenichel et al. (2013) determined that health crises such as influenza outbreaks heightened perceived risk, prompting negative behavioural changes in air travellers such as flight cancellations and the subjective preference for alternative modes of travel due to safety fears. A study by Young et al. (2014) linked depressed demand for air travel with the potential for both the in-flight transmission and the vector spread of the H1N1 virus internationally. Due to the Ebola outbreak, Cahyanto et al. (2016) found that over 50\% of the American tourists surveyed indicated that they would avoid air travel due to their risk perceptions and fear of infection during flights. As a 
result of the SARS outbreak, American tourists opted to travel domestically, but more pertinently chose to avoid air travel and opted to utilise private self-drive transport to travel to their tourist destinations (Wen et al., 2005). The following null hypotheses related to COVID-19 and the subjective safety associated with air travel and private (self-drive) transport were tested,

$\mathrm{HO}_{4}$ : The subjective safety of air travel is not influenced by perceived physical- $\left[\mathrm{HO}_{4 \mathrm{a}}\right]$, psychological- $\left[\mathrm{HO}_{4 \mathrm{~b}}\right]$, social- $\left[\mathrm{HO} \mathrm{Hc}_{4 \mathrm{c}}\right]$ risk associated with the COVID-19 pandemic.

$\mathrm{HO}_{5}$ : The subjective safety of self-drive or private transport is not influenced by perceived physical- $\left[\mathrm{H}_{5 \mathrm{a}}\right]$, psychological$\left[\mathrm{HO}_{5 \mathrm{~b}}\right]$, social- $\left[\mathrm{HO}_{5 \mathrm{c}}\right]$ risk associated with the COVID-19 pandemic.

Tourists are susceptible to cognitive biases, such as risk aversion in their tourism destination and product choices (Wattanacharoensila and La-ornual, 2019). To this end, Gstaettner et al. (2019) ascertain that risk perception and the safety of tourism products and activities are critical antecedents to tourist decision-making and behaviour. The perceived safety of both international and domestic tourism attractions is inversely correlated to the perceived risk of exposure to disease at the location (Li et al., 2017) or potentially infectious individuals most likely to be encountered at the tourism attractions (Cahyanto et al., 2016; Kock et al., 2019). In the wake of the SARS outbreak, Wen et al. (2005) observe that American tourists indicated that they were more likely to visit domestic tourism attractions as these were most likely perceived to be safer than international tourism attractions. While in the case of Chinese tourists visiting domestic attractions it emerged that hygiene and safety concerns were heightened by the SARS outbreak and influenced tourist decisions about which attractions to visit, which forms of entertainment to consume, and the choice of accommodation (Wen et al., 2005). Hence, it would be prudent to examine the potential effect of COVID-19 related risk perceptions on the subjective safety associated with visiting domestic and international tourism attractions based on the following null hypotheses,

$\mathrm{HO}_{6}$ : The subjective safety of visiting popular international tourism attractions is not influenced by perceived physical$\left[\mathrm{HO}_{6 \mathrm{a}}\right]$, psychological- $\left[\mathrm{HO}_{6 \mathrm{~b}}\right.$, social- $\left[\mathrm{HO}_{6 \mathrm{c}}\right]$ risk associated with the COVID-19 pandemic.

$\mathrm{HO}_{7}$ : The subjective safety of visiting popular domestic tourism attractions is not influenced by perceived physical- $\left[\mathrm{H}_{7 \mathrm{a}}\right]$, psychological- $\left[\mathrm{H}_{7 \mathrm{~b}}\right]$, social- $\left[\mathrm{H} 0_{7 \mathrm{c}}\right]$ risk associated with the COVID-19 pandemic.

Disease outbreaks have been linked with negative crowding behaviour due to perceived infection risk, suggesting that tourists are less likely to engage in group-oriented tourism activity as the perceived risk of disease infection increases (Wang and Ackerman, 2019). Li et al. (2017) found that the perceived crowding associated with tourism to Mount Sanqingshan National Park, a Chinese world heritage site, negatively impacted the location's subjective attractiveness and safety, thus pointing to the negative connotations of group travel.

Moreover, social crowding whereby tourists would interact with many strangers at the destination was found to impact tourist decision-making pointing to the impact of interactions with tourists of other nationalities as an antecedent to tourist travel intentions and anticipated satisfaction (Li et al., 2017). Prior tourism studies (Kock et al., 2020) have also recognized that risk perceptions induced by health crises stimulated xenophobic behaviour by tourists. Tourists associate the risk of disease infection with specific nationalities and are unwilling to travel to locations or engage in tourism that will result in their interaction with specific groups of people. For instance, Americans and Italians that presented heightened perceived risk of exposure or vulnerability to the Ebola virus exhibited xenophobic prejudices towards Africans since the virus is of African origin (Kock et al., 2020). More pertinently, xenophobic tendencies have been linked with disease avoidance behaviour and xenophobia in tourists (Cahyanto et al., 2016; Kock et al., 2019). The following null hypotheses related to COVID-19 and the subjective safety of group travel and international tourist interaction were formulated,

$\mathrm{HO}_{8}$ : The subjective safety of travelling in groups is not influenced by perceived physical- $\left[\mathrm{HO}_{8 \mathrm{a}}\right]$, psychological- $\left[\mathrm{HO}_{8 \mathrm{~b}}\right]$, social- $\left[\mathrm{HO}_{8 \mathrm{c}}\right]$ risk associated with the COVID-19 pandemic.

$\mathrm{HO}_{9}$ : The subjective safety of interacting with tourists of other nationalities is not influenced by perceived physical- $\left[\mathrm{H}_{9 \mathrm{a}}\right]$, psychological- $\left[\mathrm{H}_{9 \mathrm{~b}}\right]$, social- $\left[\mathrm{H}_{9 \mathrm{c}}\right]$ risk associated with the COVID-19 pandemic.

\section{MATERIALS AND METHODS}

A self-administered questionnaire was distributed as part of an online survey launched on the Tourism Research in Economics, Environs and Society (TREES) Facebook page. The questionnaire was designed and published on Google Forms platform - with the link to the online questionnaire being posted on the travel and tourism-oriented social media page between 7 May and 19 June 2020. This approach was similar to that of COVID-19 related studies (Li et al., 2020; Perić et al., 2021; Sánchez-Cañizares et al., 2020) that utilised social media platforms such as Facebook and Twitter to conduct surveys during the ongoing pandemic. Respondent-driven snowball sampling was implemented to grow the sample population for the study, entailing that the initial respondents were asked to invite other individuals within their social and professional network to participate in the survey (Fricker, 2008; Wejnert and Heckathorn, 2008). Logical validity of the sample was indicated by the vast majority of respondents (90.4\%) having engaged in travel and tourism activity at least once before the pandemic, as well as intending to engage in international $(82.4 \%)$ and domestic $(97.5 \%)$ tourism-oriented travel within the next two years. More significantly, a final sample of $n=323$ was achieved and deemed suitable for analysis (Goretzko et al., 2019).

In order to measure perceived risk, 12 statements were drawn from scales utilised in previous studies exploring perceived risk in tourism (see Deng and Ritchie, 2018; Fennell, 2017; Fuchs and Reichel, 2006; Khasawneh and Alfandi, 2019; Olya and Al-ansi, 2018; Sohn et al., 2016). Tourism activity was measured by eight statements which were drawn from the literature (see Adam, 2015; Olya and Al-ansi, 2018; Reisinger and Mavondo, 2005; Rittichainuwat and 
Chakraborty, 2009). Socio-demographic data were also solicited and limited to the respondents' age, gender, educational level, marital status, travel companionship, and region of residence. To ensure content validity, the survey instrument was reviewed by the North-West University's Tourism Research Scientific Committee and received ethical clearance (NWU00625-20-A4) from the faculty research ethics committee before being administered. Data were analysed utilising the Statistical Package for Social Sciences (IBM SPSS v.26) and AMOS (IBM v.26).

\section{RESULTS}

\section{Respondent profile}

The sample of $n=323$ mainly consisted of females (61.3\%), with most respondents being aged between 24 and 44 years old $(65.9 \%)$ at the time of the survey. Respondents were also highly educated [post-graduate (67.8\%) and Bachelor's (19.2\%) degree], with an even split between married (44\%) and single individuals (44\%) respondents. Most respondents travelled with either their family $(26.6 \%)$ or their partner $(22.6 \%)$ when engaging in tourism. The majority of the respondents resided on the African continent $(45.5 \%)$ with the rest indicating their respective regions of residence as Europe (23.5\%); Asia (17.3\%); North America (9\%) or Asia-Pacific (4.7\%). Notably, the internet (39.9\%); social media (26.3\%); and word-of-mouth (20.7\%) were the most influential information sources for tourist's decision-making.

\section{Validation of the conceptual model: Factor analyses}

The data for perceived risk reported a KMO of .813 and Bartlett's test of Sphericity of $\chi^{2}(66)=2199.928, p<.001$, while the data for tourism activity reported a KMO of .868 Bartlett's Test of Sphericity of $\chi^{2}(28)=1442.466, \mathrm{p}<.001$, suggesting factor analysis was possible with the data. Table 1 summarises the results of the EFA on the perceived risk dimensions and tourism activity. The EFA for perceived risk extracted the three priori dimensions which cumulatively accounted for $69.18 \%$ of the variance in the data, Physical risk $(P H R: E V=4.683, \alpha=.838)$; Psychological risk $(P S R$ : EV $=$ $1.945, \alpha=.928)$; and Social risk $(S C R: E V=1.673, \alpha=.842)$, respectively. Tourism activity loaded as one factor, TOA $(E V=$ $4.557, \alpha=.909)$, explaining $56.96 \%$ of the variance in the data. Tables 2 and 3 summarise the outcome of the CFA.

Table 1. Exploratory factor analysis - Perceived risk and tourism activity

\begin{tabular}{|c|c|c|c|c|c|c|c|c|c|c|}
\hline \multirow{2}{*}{\multicolumn{2}{|c|}{ Variable }} & \multirow{2}{*}{ *Items } & \multicolumn{2}{|c|}{ Mean $(\overline{\mathbf{x}})$} & \multicolumn{2}{|c|}{ Std. Dev ( $\sigma)$} & \multicolumn{2}{|c|}{ Communalities } & \multicolumn{2}{|c|}{$\begin{array}{l}* * \text { Factor loading } \\
\text { coefficients }\end{array}$} \\
\hline & & & Min & Max & Min & Max & Min & Max & Min & Max \\
\hline \multirow{3}{*}{$\begin{array}{l}\text { Perceived } \\
\text { risk }\end{array}$} & Physical risk (PHR) & PHR1, PHR2, PHR3, PHR4 & 3.38 & 4.20 & 1.081 & 1.321 & .625 & .754 & .674 & .896 \\
\hline & Psychological risk (PSR) & PSR1. PSR2, PSR3 & 2.20 & 2.25 & 1.277 & 1.307 & .817 & .892 & .848 & .912 \\
\hline & Social Risk (SCR) & SCR1, SCR2. SCR3, SCR4 & 2.11 & 3.15 & 1.183 & 1.322 & .639 & .811 & .708 & .834 \\
\hline $\begin{array}{l}\text { Tourism } \\
\text { activity }\end{array}$ & Tourism activity (TOA) & $\begin{array}{l}\text { TOA1, TOA2, TOA3, TOA4, } \\
\text { TOA5, TOA7, TOA8 }\end{array}$ & 2.20 & 3.27 & 1.051 & 2.259 & .461 & .756 & .679 & .870 \\
\hline
\end{tabular}

*See Appendix 1 for items statements

$* *$ Oblimin with Kaiser Normalisation, Coefficient $(\geq .50)$

Table 2. Confirmatory factor analysis - Model fit indices

\begin{tabular}{|l|c|c|c|c|c|c|c|}
\hline & $\chi^{\mathbf{2}}$ & p-value & $\chi^{\mathbf{2}}$ /DF & CFI & TLI & SRMR & RMSEA \\
\hline Perceived Risk (PHR/PSR/SCR) & 85.144 & .000 & 2.365 & .977 & .965 & .056 & .065 \\
\hline Tourism activity (TOA) & 26,150 & .004 & 2.615 & .988 & .975 & .024 & .071 \\
\hline
\end{tabular}

Notes: $\chi^{2}=$ Chi-square statistic, $\chi^{2} / \mathrm{df}=$ Relative chi-square, CFI = Comparative Fit Index ( $\left.>0.95\right)$, TLI $=$ Tucker-Lewis Index $(\geq 0.95)$, SRMR $=$ Standardised Root Mean Residual $(<0.08)$, RMSEA = Root Mean Square Error of Approximation $(<0.08)$

The respective models for perceived risk and tourism activity indicated a good fit (Table 2). Both models were within the recommended indices parameters suggested by Gaskin and Lim (2016), and Hair et al., (2014). Table 3 summarises the model validity of the perceived risk and tourism activity constructs. The CFA confirmed all the perceived risk dimensions and the tourism activity factor. No items from the EFA were dropped from the respective CFA constructs. The standardised CFA coefficients for all variables constructs were $>.50$ (Wang et al., 2020). All the measurement constructs reported composite reliabilities above $\mathrm{CR} \geq 0.70$, while the average extracted variances were above the AVE $\geq 0.50$ threshold, confirming the constructs' discriminant and convergence validity (Hu and Bentler, 1999; Wang et al., 2020).

\section{Modelling the influence of perceived risk on tourism activity}

The Pearson product correlations (Cohen, 1988) reported statistically significant moderate positive correlations ranging between $r=.326$ and $r=.426$ amongst all the perceived risk dimensions, suggesting that they were cognate as measures of perceived risk. Intriguingly, weak $(r=-.272)$ to moderate $(r=-.319)$ inverse correlations were also reported between the perceived risk dimensions and the subjective safety of tourism activity. As Table 4 summarises, the model was statistically significant, with the perceived risk dimensions explaining $14 \%$ of the variance for the subjective safety of tourism activitie $\mathrm{s}$ in the near future. The significance of the $\mathrm{R}^{2}$ statistic is supported by the literature which recommends a minimum $\mathrm{R}^{2}$ of $0.02(2 \%)$ (Cohen, 1988), while more specifically within the social sciences, Ferguson (2009) recommends a minimum $\mathrm{R}^{2}$ of $0.04(4 \%)$ for practical effect significance. There were no multicollinearity concerns noted based on the Tolerance $(>.10)$ and VIF (<10) statistics, respectively (Hair et al., 2014). As it emerged, physical $(P H R: \beta=-.141, t=-2.393, \mathrm{p}<.05)$, psychological (PSR: $\beta=-.115, t=-2.026, \mathrm{p}<.05)$, and social $(S C R: \beta=-.219, t=-3.690, \mathrm{p}<.001)$ risk associated with the 
COVID-19 pandemic had a negative statistically significant influence on the subjective safety of tourism activities in the near future (Table 4). This suggests that as perceived risk related to the COVID-19 pandemic increases within the near future, the subjective safety associated with tourism activities reduces.

Table 3.Confirmatory factor analysis - Model validity

\begin{tabular}{|c|c|c|c|c|c|c|c|c|c|c|}
\hline \multirow[t]{2}{*}{ Latent construct } & & \multirow[t]{2}{*}{\begin{tabular}{|c|}
$\begin{array}{c}\text { Observed } \\
\text { variables }\end{array}$ \\
\end{tabular}} & \multicolumn{2}{|c|}{\begin{tabular}{|c|}
$\begin{array}{c}\text { Standardised } \\
\text { Coefficients }\end{array}$ \\
\end{tabular}} & \multirow[t]{2}{*}{\begin{tabular}{|c|} 
Composite \\
Reliability (CR) \\
\end{tabular}} & \multirow[t]{2}{*}{\begin{tabular}{|c|} 
Average Variance \\
Extracted (AVE)
\end{tabular}} & \multirow[t]{2}{*}{ TOA } & \multirow[t]{2}{*}{ PHR } & \multirow[t]{2}{*}{ PSR } & \multirow[t]{2}{*}{ SCR } \\
\hline & & & Min & Max & & & & & & \\
\hline Tourism Activity & & 7 & .581 & .848 & .906 & .581 & .763 & & & \\
\hline \multirow[t]{3}{*}{ Perceived Risk } & Physical Risk (PHR) & 4 & .733 & .786 & .806 & .513 & . & .717 & & \\
\hline & Psychological Risk (PSR) & 3 & .836 & .953 & .930 & .816 & . & $355 * * *$ & .903 & \\
\hline & Social Risk $(S C R)$ & 4 & .563 & .952 & .872 & .636 & . & $.351 * * *$ & $.572 * * *$ & .797 \\
\hline
\end{tabular}

Table 4. Multiple regression analysis - The influence of perceived risk on the subjective safety of post-pandemic tourism activity

\begin{tabular}{|c|c|c|c|c|c|c|c|c|}
\hline & \multicolumn{2}{|c|}{ Unstandardised coefficients } & \multirow{2}{*}{$\begin{array}{c}\text { Standardised coefficients } \\
\beta \\
\end{array}$} & \multirow[b]{2}{*}{ t-value } & \multirow[b]{2}{*}{ Sig. } & \multirow[b]{2}{*}{ Tol. } & \multirow[b]{2}{*}{ VIF } & \multirow{2}{*}{ Нyp. } \\
\hline & B & SE & & & & & & \\
\hline \multicolumn{9}{|c|}{ DV: Subjective Safety of Tourism Activity } \\
\hline \multicolumn{9}{|c|}{$\mathrm{R}^{2}=.135, \mathrm{~F}(3,319) 16.641, \mathrm{p}=.000$} \\
\hline IV: Physical risk $(P H R)$ & -.137 & .057 & -.141 & -2.393 & $.017 *$ & .782 & 1.279 & $\mathrm{HO}_{\mathrm{la}}$ \\
\hline IV: Psychological risk (PSR) & -.092 & .045 & -.115 & -2.026 & $.044^{*}$ & .841 & 1.189 & $\mathrm{HO}_{\mathrm{lb}}$ \\
\hline IV: Social risk $(S C R)$ & -.205 & .056 & -.219 & -3.690 & $000^{* * * *}$ & .770 & 1.299 & $\mathrm{H}_{1 \mathrm{c}}$ \\
\hline
\end{tabular}

Statistically significant at $* \mathrm{p}<.05, * * \mathrm{p}<.01, * * * \mathrm{p}<.001$

Table 5. Multiple regression analysis - The influence of perceived risk on the subjective safety of specific tourism activities

\begin{tabular}{|c|c|c|c|c|c|c|}
\hline & \multicolumn{2}{|c|}{ Unstandardised coefficients } & \multirow{2}{*}{\begin{tabular}{|c|} 
Standardised coefficients \\
$\beta$ \\
\end{tabular}} & \multirow{2}{*}{ t-value } & \multirow{2}{*}{ Sig. } & \multirow{2}{*}{ Hyp. } \\
\hline & B & SE & & & & \\
\hline \multicolumn{7}{|l|}{ DV: International travel } \\
\hline \multicolumn{7}{|c|}{$\mathrm{R}^{2}=.132, \mathrm{~F}(3,319) 16.150, \mathrm{p}=.000$} \\
\hline IV: Physical risk $(P H R)$ & -.249 & .069 & -.212 & -3.600 & $.000 * * *$ & $\mathrm{HO}_{2 \mathrm{a}}$ \\
\hline IV: Psychological risk $(P S R)$ & -.111 & .055 & -.115 & -2.022 & $.044 *$ & $\mathrm{HO}_{2 \mathrm{~b}}$ \\
\hline IV: Social risk $(S C R)$ & -.162 & .067 & -.143 & -2.401 & $.017 *$ & $\mathrm{HO}_{2 \mathrm{c}}$ \\
\hline \multicolumn{7}{|l|}{ DV: Domestic travel } \\
\hline \multicolumn{7}{|c|}{$\mathrm{R}^{2}=.073, \mathrm{~F}(3,319) 8.395, \mathrm{p}=.000$} \\
\hline IV: Physical risk $(P H R)$ & -.067 & .065 & -.063 & -1.035 & .301 & $\mathrm{HO}_{3 \mathrm{a}}$ \\
\hline IV: Psychological risk $(P S R)$ & -.098 & .051 & -.113 & -1.919 & .056 & $\mathrm{HO}_{3 \mathrm{~b}}$ \\
\hline IV: Social risk $(S C R)$ & -.175 & .063 & -.171 & -2.785 & $.006 * *$ & $\mathrm{HO}_{3 \mathrm{c}}$ \\
\hline \multicolumn{7}{|l|}{ DV: Travelling by air } \\
\hline \multicolumn{7}{|c|}{$\mathrm{R}^{2}=.118, \mathrm{~F}(3,319) 14.182, \mathrm{p}=.000$} \\
\hline IV: Physical risk $(P H R)$ & -.159 & .076 & -.125 & -2.096 & $.037 *$ & $\mathrm{HO}_{4 \mathrm{a}}$ \\
\hline IV: Psychological risk $(P S R)$ & -.095 & .060 & -.091 & -1.579 & .115 & $\mathrm{HO}_{4 \mathrm{~b}}$ \\
\hline IV: Social risk $(S C R)$ & -.272 & .074 & -.222 & -3.698 & $.000 * * *$ & $\mathrm{HO}_{4 \mathrm{c}}$ \\
\hline \multicolumn{7}{|c|}{ DV: Visiting popular international tourist attractions } \\
\hline \multicolumn{7}{|c|}{$\mathrm{R}^{2}=.069, \mathrm{~F}(3,319) 7.880, \mathrm{p}=.000$} \\
\hline IV: Physical risk $(P H R)$ & -.041 & .074 & -.034 & -.552 & .582 & $\mathrm{HO}_{6 \mathrm{a}}$ \\
\hline IV: Psychological risk $(P S R)$ & -.108 & .059 & -.108 & -1.825 & .069 & $\mathrm{HO}_{6 \mathrm{~b}}$ \\
\hline IV: Social risk $(S C R)$ & -.219 & .072 & -.186 & -3.026 & $.003 * *$ & $\mathrm{HO}_{6 \mathrm{c}}$ \\
\hline \multicolumn{7}{|c|}{ DV: Visiting popular local tourist attractions } \\
\hline \multicolumn{7}{|c|}{$\mathrm{R}^{2}=.075, \mathrm{~F}(3,319) 8.663, \mathrm{p}=.000$} \\
\hline IV: Physical risk $(P H R)$ & .038 & .073 & .032 & .519 & .604 & $\mathrm{H}_{7 \mathrm{a}}$ \\
\hline IV: Psychological risk $(P S R)$ & -.121 & .058 & -.124 & -2.107 & $.036^{*}$ & $\mathrm{HO}_{7 \mathrm{~b}}$ \\
\hline IV: Social risk $(S C R)$ & -.254 & .071 & -.220 & -3.594 & $.000 * * *$ & $\mathrm{HO}_{7 \mathrm{c}}$ \\
\hline \multicolumn{7}{|l|}{ DV: Travelling in groups } \\
\hline \multicolumn{7}{|c|}{$\mathrm{R}^{2}=.061, \mathrm{~F}(3,319) 6.965, \mathrm{p}=.000$} \\
\hline IV: Physical risk $(P H R)$ & -.176 & .078 & -.139 & -2.274 & $.024 *$ & $\mathrm{H}_{8 \mathrm{a}}$ \\
\hline IV: Psychological risk $(P S R)$ & -.045 & .062 & -.044 & -.739 & .460 & $\mathrm{HO}_{8 \mathrm{~b}}$ \\
\hline IV: Social risk $(S C R)$ & -.158 & .075 & -.130 & -2.097 & $.037 *$ & $\mathrm{HO}_{8 \mathrm{c}}$ \\
\hline \multicolumn{7}{|c|}{ DV: Interacting with tourists of other nationalities } \\
\hline \multicolumn{7}{|c|}{$\mathrm{R}^{2}=.137, \mathrm{~F}(3,319) 16.900, \mathrm{p}=.000$} \\
\hline IV: Physical risk $(P H R)$ & -.302 & .074 & -.241 & -4.091 & $.000 * * *$ & $\mathrm{HO}_{9 \mathrm{a}}$ \\
\hline IV: Psychological risk $(P S R)$ & -.064 & .059 & -.062 & -1.087 & .278 & $\mathrm{HO}_{9 \mathrm{~b}}$ \\
\hline IV: Social risk $(S C R)$ & -.195 & .072 & -.161 & -2.715 & $.007 * *$ & $\mathrm{HO}_{9 \mathrm{c}}$ \\
\hline
\end{tabular}

Statistically significant at $* \mathrm{p}<.05, * * \mathrm{p}<.01, * * * \mathrm{p}<.00$ 
Thus, null hypotheses $\mathrm{H}_{1 \mathrm{a}}, \mathrm{H}_{1 \mathrm{~b}}$ and $\mathrm{HO}_{1 \mathrm{c}}$ were rejected, perceived physical, psychological, social risk associated with the COVID-19 pandemic significantly influences the subjective safety of tourism activity in the near future. To gain more insight into this nexus, the data were subjected to further linear regression analyses in line with the approach adopted by van Dyk et al., (2019). Regressions were conducted between the respective statistically significant perceived risk dimensions and each post-pandemic tourism activity. All the regression models were statistically significant (Table 5), with $\mathrm{R}^{2}$ statics for the respective models being above the recommended minimum $\mathrm{R}^{2}$ of .04 (4\%) for practical effect significance (Ferguson, 2009). There was an absence of multicollinearity in all the respective models, PHR: Tolerance of .782 and VIF of 1.279; PSR: Tolerance of .841 and VIF of 1.189; and SCR: Tolerance of .770 and VIF of 1.299.

As summarised in Table 5, perceived physical risk $(P H R)$ reported a statistically significant inverse predictive effect on tourist's subjective safety associated with international $(\beta=-.212, \mathrm{p}<.001)$; air $(\beta=-.125, \mathrm{p}<.05)$; and group $(\beta=-.139$, $\mathrm{p}$ $<.05)$ travel; as well as the subjective safety of interaction with tourists of other nationalities $(\beta=-.241, \mathrm{p}<.001)$. The finding suggests that as physical risk perceptions associated with the COVID-19 pandemic increased, the aforementioned tourism activities' perceived safety diminished. Hence, null hypotheses $\mathrm{H}_{2}, \mathrm{H}_{4 \mathrm{a}}, \mathrm{H}_{8 \mathrm{a}}$ and $\mathrm{H}_{9 \mathrm{a}}$ were rejected. Whereas, null hypotheses $\mathrm{HO}_{3 \mathrm{a}}, \mathrm{HO}_{6 \mathrm{a}}$ and $\mathrm{HO}_{7 \mathrm{a}}$ were confirmed since perceived physical risk $(P H R)$ associated with the COVID-19 pandemic did not influence domestic travel's subjective safety as the subjective safety of visiting both popular international and domestic tourist attractions. Perceived psychological risk (PSR) reported a statistically significant inverse predictive effect on the subjective safety tourists associated with international travel $(\beta=-.115, \mathrm{p}<.05)$ and visiting popular local tourist attractions $(\beta=-.124, \mathrm{p}<.05)$. The findings suggest that as psychological risk factors associated with the pandemic increase, the safety of international travel and visiting popular local tourist attractions in the near future reduces.

Therefore, null hypotheses $\mathrm{H}_{2 \mathrm{~b}}$ and $\mathrm{H}_{7 \mathrm{~b}}$ were rejected. While, null hypotheses $\mathrm{H}_{3 \mathrm{~b}}, \mathrm{H}_{4 \mathrm{~b}}, \mathrm{H}_{6 \mathrm{~b}}, \mathrm{H}_{8 \mathrm{~b}}$ and $\mathrm{H} 0_{9 \mathrm{~b}}$ were confirmed, perceived psychological risk (PSR) did not influence tourist's subjective safety of domestic travel; travelling by air; visiting popular international tourist attractions; travelling in groups, and interacting with tourists of other nationalities in the near future. Notably, perceived social risk $(S C R)$ had a statistically significant inverse predictive effect on the subjective safety associated with all the tourism activities, namely: international $(\beta=-.143, \mathrm{p}<.05)$ and domestic $(\beta=-.171, \mathrm{p}<.01)$ travel; visiting popular international $(\beta=-.186, \mathrm{p}<.01)$ and local $(\beta=-.220, \mathrm{p}<.001)$ tourist attractions; air travel $(\beta=-.222, \mathrm{p}<.001)$; group travel $(\beta=-.130, \mathrm{p}<.05)$; as well as tourist's interaction with tourists of other nationalities $(\beta=-.161, \mathrm{p}<.01)$. The finding suggests that as the social risks associated with the COVID-19 pandemic increase, the perceived safety of all the tourism activities explored in this study decreases. Thus, null hypotheses $\mathrm{HO}_{2 \mathrm{c}}, \mathrm{HO}_{3 \mathrm{c}}, \mathrm{HO}_{4 \mathrm{c}}, \mathrm{HO}_{6 \mathrm{c}}, \mathrm{H}_{7 \mathrm{c}}, \mathrm{H}_{8 \mathrm{c}}$ and $\mathrm{H}_{9 \mathrm{c}}$ were rejected.

\section{DISCUSSION AND CONCLUSION}

The purpose of the study was to explore the nexus between the risk perceptions associated with the COVID-19 pandemic and the subjective safety of tourism activity in the near future. Notwithstanding, the literature supporting the correlation between the pandemic-related perceived risk and tourism activity (Li et al., 2020; Liu et al., 2013; Olya and Alansi, 2018; Seabra et al., 2013), there is extensive empirical evidence of the influence of pandemic-induced physical, psychological and social risk perception on subjective safety of specific tourism activity in the near future. Physical risk related to healthcare standards, the sanitation and hygiene of the tourist destination, the risk of infection, and the pervasiveness of the outbreak in neighbouring countries, diminished how safe tourists perceived international, air and group travel, respectively, as well as interacting with tourists of other nationalities to be.

This finding is corroborated by the literature (Abraham et al., 2020; Qiu et al., 2020), which associates international travel with vector disease transmission in the SARS, H1N1 and Ebola virus instances outbreaks. Moreover, national governments are propagating the notion of international travel as the primary mode of the global spread of the COVID-19 virus (Chua et al., 2020; Beck and Hensher, 2020). Relatedly, demand for air travel has been severely impacted by the ongoing COVID-19 virus pandemic due to, in part, risk perceptions heightened by government interventions that have restricted air travel, as well as the health warnings associated with 'public' transport due to the COVID-19 virus's hyper-transmissibility and air travel being viewed as being very unsafe in light of the pandemic (Beck and Hensher, 2020; Chua et al., 2020). Prior studies (Li et al., 2017; Wang and Ackerman, 2019) have established that negative crowding behaviour associated with group-oriented tourism activity stemmed from heightened safety concerns induced by perceived infection risk. Furthermore, previous studies (Cahyanto et al., 2016; Kock et al., 2020) have also established a link between perceived physical health risk and the development of xenophobic behaviour in tourists; thus the physical risk associated with the COVID-19 pandemic may also result in tourists viewing interaction with tourists from certain countries as being unsafe or risky.

This study also confirms that psychological risk related to the tension, worry and discomfort associated with travel and tourism in the era of COVID-19 also diminished how safe travelling internationally and visiting popular local tourist attractions was perceived by potential tourists. Sánchez-Cañizares et al. (2020) support this finding, suggesting that psychological barriers associated with health and hygiene reduce the likelihood of tourists engaging in international travel due to heightened anxiety, uncertainty and general safety concerns. Moreover, Zhang et al. (2020) suggest that psychological responses to the subjective safety of international travel associated with the COVID-19 pandemic also vary depending on the risk of infection related to the country being considered an international tourism destination.

The propensity of the COVID-19 virus's spread through direct and indirect human contact has resulted in stringent lockdown measures aimed at limiting human contact (de Vos, 2020; Lapointe, 2020). Hence, the moratoriums on nonessential travel, including tourist attractions' patronage (Zhang et al., 2020). Previous experience from the Ebola virus in the USA (Cahyanto et al., 2016), and SARS in China (Dombey, 2003; Li et al., 2017) shows that domestic tourists also worry about the safety of visiting popular local attractions during disease outbreaks. 
Lastly, the study confirms that social risk related to how tourist's social reference groups (acquaintances, friends and family) may disapprove of their engaging in tourism activity, as well as the negative effect that tourism activity may have on their image in society, also diminished the subjective safety of tourism activity. Wattanacharoensila and La-ornual (2019) acknowledge the influence of social bias in tourist decision-making, particularly the social 'conflict' and dissonance that may arise from stereotypes associated with tourists' choices. To this end, prior studies have established that social predispositions either positively or negatively impact decisions related to the scope of tourism (Chen et al., 2013) and tourism product choices (Gstaettner et al., 2019). Thus, supporting the potential influence of social risk associated with the COVID-19 pandemic on tourism safety. The COVID-19 pandemic is a 'social' disease (Chua et al., 2020; Beck and Hensher, 2020), and the literature shows that the conditioning of individuals to avoid human contact in-order to stem the spread of the virus through social distancing interventions has instigated drastic reductions in tourism demand (Bae and Chang, 2020; Cifuentes-Faura, 2020). The promotion of social distancing behaviour has also significantly influenced the travel mode choices both available to and preferred by individuals (de Vos, 2020).

For instance, prior research has observed that perceived risk influences tourist decision-making related to group travel (package tours) or private travel activities (Adam, 2015). More pertinently, Lachance (2020) notes that the ongoing COVID-19 pandemic and the subsequent social distancing measures instituted by multiple national governments have significantly constrained travel and tourism activity including, at one point or another, all domestic and international recreational endeavours. Intriguingly, recent studies (Aguilera, 2020; Jamal and Budke, 2020) have also established that the fear and uncertainty surrounding the origins and transmissibility of the COVID-19 virus have heightened socially-oriented risk and manifested as discrimination against and xenophobia towards primarily Chinese nationals globally, as well as international travellers visiting foreign countries in general (Qiu et al., 2020).

In sum, the perceived risk associated with the COVID-19 pandemic is a multidimensional construct that negatively influences tourists' subjective safety of tourism activity. While there is some evidence of the influence of perceived risk related to the ongoing COVID-19 pandemic on tourist behaviour - primarily in terms of travel intentions - the present study presents novel findings that conclude that risk perceptions associated with the ongoing COVID-19 pandemic are a significant antecedent to the subjective safety of tourism activities in the near future.

\section{Managerial Implications and Recommendations}

In the era of COVID-19, the level of safety associated with tourism activity is imperative for both tourism sector recovery and the stimulation of tourism demand throughout the tourism value chain. Two significant managerial implications are discussed. First, public diplomacy as a specialised form of marketing communications will form the critical basis for evidence-based marketing meant to disseminate information crucial to the crisis and post-crisis communicationcentric activities of tourism destinations. Government-led non-pharmaceutical interventions [domestic and international lockdowns] may be partially responsible for how unsafe tourism activity may be perceived to be in light of the pandemic.

It is recommended that national governments, tourism and health-oriented quasi-governmental organisations play a critical role in the concerted effort to manage the perceived safety of tourism activity and recover tourist confidence and trust in the safety of tourism at their respective destinations as part of public diplomacy. Public diplomacy as a multi-stakeholder marketing approach should involve the transparent and effective communication of the virus and infection protective measures in place to protect tourists such as the responsible opening up of national borders; the implementation of strict, but convenient and non-invasive immigration procedures; the transparent monitoring of compliance with health and safety measures throughout the tourism value chain; as well as the strengthening of public resource infrastructure such as hospitals. This process should complement an integrated crisis communications marketing strategy by DMO's to effectively communicate to tourists both the covert and overt health and safety measures to ensure tourists' safety throughout the tourism experience.

Second, given the pervasiveness of the psychological and social risk associated with contemporary touris $\mathrm{m}$ activity, tourism-oriented social marketing is recommended as it will be crucial to the social re-engineering of tourist behaviour during and post the crises. Inducing and incentivising health and safety-conscious behaviour as part of the tourism experience will improve tourism's subjective safety. Social marketing-oriented tourism promotion will motivate tourists to adjust to the 'new normal' impelled by the COVID-19 pandemic, and serve to inform tourists of the evolution of the tourism value chain in response to tourists' new requirements and expectations. For instance, product innovation in the airline sector such as a complete shift towards completely digital ticketing and check-in, the installation of surgical theatre-grade air filtration systems and more socially distant seating on aircraft, as well as the introduction of complimentary travel health insurance will go a long way in restoring tourist trust and confidence in air travel.

Whereas, tourism destinations may also focus on product innovations such as the promotion of more nature and outdoor activity-based tourism, as well as creating packages for smaller tourist groups for group tourism activities like bus tours, cruises or visits to indoor facilities to manage social crowding will also mitigate infection fears due to crowding concerns. Incentives such as complimentary destination branded face masks and hand sanitisers for visitors, or discounts for tourists who voluntarily undergo COVID-19 screening at tourism facilities (hotels, attractions, bars, restaurants) and attractions sites (theme parks, museums) will also promote safer, more socially responsible tourism.

A follow-up longitudinal study may be conducted to confirm the present study's findings in light of various vaccines' development and the emergence of the second wave of infections in most countries. Owing to the dynamic nature of the COVID-19 pandemic and its impact on the global tourism value chain, further research is recommended into the pandemic's potential influence on tourist decision-making and behaviour as the crisis evolves. It is recommended that future predictive tourism research associated with the COVID-19 pandemic pay particular attention to the psycho-social impacts of the virus 
on decision-making beyond the archetypal health risk associated with the pandemic. Moreover, academic inquiry into the influence of pandemics on the subjective safety of specific tourism activities across the tourism value-chain will benefit and aid tourism practitioners and service providers in their post-pandemic recovery strategies.

\section{REFERENCES}

Abraham, V., Bremser, K., Carreno, M., Crowley-Cyr, L., \& Moreno, M. (2020). Exploring the consequences of COVID-19 on tourist behaviours: perceived travel risk, animosity and intentions to travel. Tourism Review. https://doi.org/10.1108/TR-07-2020-0344

Adam, I. (2015). Backpackers' risk perceptions and risk reduction strategies in Ghana. Tourism Management, 49, 99-108. https://doi.org/10. 1016/j.tourman.2015.02.016

An, M., Lee, C., \& Noh, Y. (2010). Risk factors at the travel destination: their impact on air travel satisfaction and repurchase intention. Serv Bus 4, 155-166.

Bae, S.Y., \& Chang, P.J. (2020). The effect of coronavirus disease-19 (COVID-19) risk perception on behavioural intention towards 'untact' tourism in South Korea during the first wave of the pandemic (March 2020). Current Issues in Tourism, https://doi.org/10.1080/13683500.2020.1798895

Beck, M., \& Hensher, D.A. (2020). Insights into the impact of Covid-19 on household travel, work, activities and shopping in Australia - the early days under restrictions (ITLS working paper 20-09). https://ses.library.usyd.edu.au/bitstream/handle/2123/22247/ITLS-WP-2009. pdf?sequence $=3 \&$ is Allowed $=y$

Boksberger, P.E., Bieger, T., \& Laesser, C. (2007). Multidimensional analysis of perceived risk in commercial air travel. Journal of Air Transport Management, 13(2), 90-96,

Bowen, J.T., \& Laroe, C. (2006). Airline networks and the international diffusion of Severe Acute Respiratory Syndrome (SARS). The Geographical Journal, 172(2),130-144.

Cahyanto, I., Wiblishauser, M., Pennington-Gray, L., \& Schroeder, A. (2016). The dynamics of travel avoidance: The case of Ebola in the US. Tourism Management Perspectives, 20, 195-203.

Carter, S. (1998). Tourists' and travellers' social construction of Africa and Asia as risky locations. Tourism Management, 19(4), 349-358.

Chen, C.C., Lin, Y.H., \& Petrick, J.F. (2013). Social Biases of Destination Perceptions. Journal of Travel Research, 52(2), $240-252$.

Chua, B.L., Al-Ansi, A., Lee, M.J., \& Han, H. (2020). Impact of health risk perception on avoidance of international travel in the wake of a pandemic. Current Issues in Tourism, https://doi.org/10.1080/13683500.2020.1829570.

Cifuentes-Faura, J. (2020). The importance of behavioural economics during COVID-19. Journal of Economics and Behavioural Studies, 12(3), 70-74. https://doi.org/10.22610/jebs.v12i3(J).3038

Cohen, J. (1988). Statistical power analysis for the behavioural sciences, 2nd edition. New York: Erlbaum.

De Vos, J. (2020). The effect of COVID-19 and subsequent social distancing on travel behaviour. Transportation Research Interdisciplinary Perspectives, 5, 100121.

Deng, R., \& Ritchie, B.W. (2018). International university students' travel risk perceptions: an exploratory study. Current Issues in Tourism, 21(4), 455-476. https://doi.org/10.1080/13683500.2016.1142939

Dombey, O. (2003). The effects of SARS on the Chinese tourism industry. Journal of Vacation Marketing, 10(1), 4-10.

Fenichel, E.P., Kuminoff, N.V., \& Chowell, G. (2013). Skip the trip: Air travellers' behavioural responses to pandemic influenza. PLoS One, 8(3). 58249. https://doi.org/10.1371/journal.pone.0058249

Fennel, D.A. (2017). Towards a model of travel fear. Annals of Tourism Research, 60, 140-150. http://dx.doi.org/10.1016/j.annals.2017.07.015

Ferguson, C.J. (2009). An effect size primer: A guide for clinicians and researchers. Professional Psychology: Research and Practice, 40(5), 532-538.

Fricker, R.D. (2008). Sampling methods for web and e-mail surveys. The Sage handbook of online research methods.

Fuchs, G., \& Reichel, A. (2006). Tourist destination risk perception: The case of Israel. Journal of Hospitality and Leisure Marketing, 14(2), 83-108. https://doi.org/10.1300/J150v14n02_06

Garg, A. (2013). A study of tourist perception towards travel risk factors in tourist decision making. Asian Journal of Tourism and Hospitality Research, 7(1), 47-57.

Global Rescue \& World Travel and Tourism Council. (2019). Crisis Readiness: Are You Prepared and Resilient to Safeguard Your People and Destinations? World Travel and Tourism Council, London.

Goretzko, D., Pham, T.T.H., \& Bühner, M. (2019). Exploratory factor analysis: Current use, methodological developments and recommendations for good practice. Current Psychology. https://doi.org/10.1007/s12144-019-00300-2

Griffiths, S., \& Lau, J. (2009). The influence of SARS on perceptions of risk and reality. Journal of Public Health, $31(4), 466-467$. https://doi.org/10.1093/pubmed/fdp094

Gstaettner, A.M., Lee, D., Weiler, B., \& Rodger, K. (2019). Visitor safety in recreational protected areas: Exploring responsibility sharing from a management perspective. Tourism Management, 75, 370-380. https://doi.org/10.1016/j.tourman.2019.06.007

Hair, J.F., Black, W.C., Babin, B.J., \& Anderson, R.E. (2014). Multivariate data analysis, $7^{\text {th }}$ Ed. Harlow: Pearson Education Limited.

Haque, T.H., \& Haque, M.O. (2018). The swine flu and its impacts on tourism in Brunei. Journal of Hospitality and Tourism Management, $36,92-101$.

Henderson, J.C. (2003). Managing a health-related crisis: SARS in Singapore. Journal of Vacation Marketing, 10(1), 67-77.

Hu, L., \& Bentler, P.M. (1999). Cutoff criteria for fit indexes in covariance structure analysis: Conventional criteria versus new alternatives. Structural Equation Modeling: A MultidisciplinaryJournal, 6(1), 1-55.

Jamal, T., \& Budke, C. (2020). Tourism in a world with pandemics: local-global responsibility and action. Journal of Tourism Futures, 6(2), 181-188. https://doi.org/10.1108/JTF-02-2020-0014

Karl, M., \& Schmude, J. (2017). Understanding the role of risk (perception) in destination choice: A literature review and synthesis. Tourism, 65(2), $138-155$.

Khasawneh, M.S., \& Alfandi, A.M. (2019). Determining behaviour intentions from the overall destination image and risk perception. Tourism and Hospitality Management, 25(2), 355-375. https://doi.org/10.20867/thm.25.2.6

Kock, F., Josiassen, A., \& Assaf, A.G. (2019). The xenophobic tourist. Annals of Tourism Research, 74, 155-166.

Kock, F., Nørfelt, A., Josiassen, A., Assaf, A.G., \& Tsionas, M.G. (2020). Understanding the COVID-19 tourist psyche: The evolutionary tourism paradigm. Annals of Tourism Research, 85, 103053. https://doi.org/10.1016/j.annals.2020.103053

Kuo, H.I., Chen, C.C., Tseng, W.C., Ju, L.F., \& Huang, B.W. (2008). Assessing impacts of SARS and Avian Flu on international tourism demand to Asia. Tourism Management, 29, 917-928. 
Lachance, E.L. (2020). COVID-19 and its Impact on Volunteering: Moving Towards Virtual Volunteering. Leisure Sciences. https://doi.org/10.1080/01490400.2020.1773990

Lapointe, D. (2020). Reconnecting tourism after COVID-19: The paradox of alterity in tourism areas. Tourism Geographies. https://doi.org/10.1080/14616688.2020.1762115

Li, J., Nguyen, T.H.H., \& Coca-Stefaniak, J.A. (2020). Coronavirus impacts on post-pandemic planned travel behaviours. Annals of Tourism Research, https://doi.org/10.1016/j.annals.2020.102964

Li, L., Zhang, J., Nian, S., \& Zhang, H. (2017). Tourists' perceptions of crowding, attractiveness, and satisfaction: A second-order structural model. Asia Pacific Journal of Tourism Research, 22(12), 1250-1260.

Liu, B., Pennington-Gray, L., \& Schroeder, A. (2013). Images of safe tourism destinations in the United States held by African Americans. PASOS. Revista de Turismo y Patrimonio Cultural, 11(3), Special Issue, 105-121.

Matiza, T. (2020). Post-COVID-19 crisis travel behaviour: towards mitigating the effects of perceived risk. Journal of Tourism Futures. http://dx.doi.org/10.1108/JTF-04-2020-0063

Neuburger, L., \& Egger, R. (2020). Travel risk perception and travel behaviour during the COVID-19 pandemic 2020: a case study of the DACH region. Current Issues in Tourism. https://doi.org/10.1080/13683500.2020.1803807

Olya, H.G.T., \& Al-ansi, A. (2018). Risk assessment of halal products and services: Implication for tourism industry. Tourism Management, 65 (2018), 279-291. https://doi.org/10.1016/j.tourman.2017.10.015

Page, S., Song, H., \& Wu, D.C. (2012). Assessing the impacts of the global economic crisis and swine flu on inbound tourism demand in the United Kingdom. Journal of Travel Research, 51(2), 142-153. https://doi.org/10.1177/0047287511400754

Perić, G., Dramićanin, S., \& Conić, M. (2021). The impact of Serbian tourists' risk perception on their travel intentions during the COVID-19 pandemic. European Journal of Tourism Research, 27, 2705.

Qi, C.X., Gibson, H.J., \& Zhang, J.J. (2009). Perceptions of Risk and Travel Intentions: The Case of China and the Beijing Olympic Games. Journal of Sport \& Tourism, 14(1), 43-67. https://doi.org/10.1080/14775080902847439.

Qiu, R.T.R., Park, J., Li, S., \& Song, H. (2020). Social costs of tourism during the COVID-19 pandemic. Annals of Tourism Research, 84, 102994. https://doi.org/10.1016/j.annals.2020.102994

Reisinger, Y., \& Mavondo, F. (2005). Travel anxiety and intentions to travel internationally: Implications of travel risk perception. Journal of Travel Research, 43(3), 212-225. https://doi.org/10.1177\%2F0047287504272017

Rittichainuwat, B.N., \& Chakraborty, G. (2009). Perceived travel risks regarding terrorism and disease: The case of Thailand. Tourism Management, 30(3), 410-418. https://doi.org/10.1016/j.tourman.2008.08.001

Salazar, N.B. (2005). Tourism and glocalisation "Local" Tour Guiding. Annals of Tourism Research, 32(3), 628-646.

Sánchez-Cañizares, S.M., Cabeza-Ramírez, L.J., Muñoz-Fernández, G., \& Fuentes-García, F.J. (2020). Impact of the perceived risk from Covid-19 on intention to travel. Current Issues in Tourism. https://doi.org/10.1080/13683500.2020.1829571

Seabra, C., Dolnicar, S., Abrantes J.L., \& Kastenholz, E. (2013). Heterogeneity in risk and safety perceptions of international tourists. Tourism Management, 36, 502-510. http://dx.doi.org/10.1016/j.tourman.2012.09.008

Shaheer, I., Carr, N., \& Insch, A. (2019). What are the reasons behind tourism boycotts? Anatolia, 30(2), 294-296. https://doi.org/ $10.1080 / 13032917.2018 .1562948$

Sohn, H.K., Lee, T.J., \& Yoon, Y.S. (2016). Relationship between perceived risk, evaluation, satisfaction, and behavioural intention: A case of local-festival visitors. Journal of Travel and Tourism Marketing, 33(1), 28-45. https://doi.org/10.1080/10548408.2015.1024912.

van Dyk, A., Tkaczynski, A., \& Slabbert, E. (2019). Repeat tourism, destination image and behavioural intentions: implications for sustainable development in South Africa. Tourism Recreation Research, 44(3), 392-398. http://dx.doi.org/10.1080/02508281.2019.1637610

Wachyuni, S.S., \& Kusumaningrum, D.A. (2020). The Effect of COVID-19 Pandemic: How are the Future Tourist Behavior? Journal of Education, Society and Behavioural Science, 33(4), 67-76. https://doi.org/10.9734/jesbs/2020/v33i430219

Wang, F., Xue, T., Wang, T., \& Wu, B. (2020). The mechanism of tourism risk perception in severe epidemic - The antecedent effect of place image depicted in anti-epidemic music videos and the moderating effect of visiting history. Sustainability, 12. http://dx.doi.org/10.3390/su12135454

Wang, I.M., \& Ackerman, J.M. (2019). The infectiousness of crowds: Crowding experiences are amplified by pathogen threats. Personality and Social Psychology Bulletin, 45(1), 120-132. https://doi.org/10.1177/0146167218780735

Wang, Y.S. (2009). The impact of crisis events and macroeconomic activity on Taiwan's international inbound tourism demand. Tourism Management, 30(1), 75-82.

Wattanacharoensila, W., \& La-ornual, D. (2019). A systematic review of cognitive biases in tourist decisions. Tourism Management, 75, 353-369. https://doi.org/10.1016/j.tourman.2019.06.006

Wejnert, C., \& Heckathorn, D.D. (2008). Web-Based network sampling efficiency and efficacy of respondent-driven sampling for online research. Sociological Methods and Research, 37(1), 105-134.

Wen, Z., Huimin, G., \& Kavanaugh, R.R. (2005). The impacts of SARS on the consumer behaviour of Chinese domestic tourists. Current Issues in Tourism, 8(1), 22-38. https://doi.org/10.1080/13683500508668203

Young, N., Pebody, R., Smith, G., Olowokure, B., Shankar, G., Hoschler, K., Galiano, M., Green, H., Wallensten, A., Hogan, A., \& Olivera, I. (2014). International flight-related transmission of pandemic influenza A(H1N1)pdm09: An historical cohort study of the first identified cases in the United Kingdom. Influenza and Other Respiratory Viruses, 8(1), 66-73. https://doi.org/10.1111/irv.12181

Zhang, K., Hou, Y., \& Li, G. (2020). Threat of infectious disease during an outbreak: Influence on tourists' emotional responses to disadvantaged price inequality. Annals of Tourism Research, 84, 102993. https://doi.org/10.1016/j.annals.2020.102993

*** Aguilera (2020). Xenophobia 'is a pre-existing condition', how harmful stereotypes and racism are spreading around the coronavirus. TIME Health 2019-NCOV. https://time.com/5775716/xenophobia-racism-stereotypes-coronavirus/

*** Gaskin, J., \& Lim, J. (2016). Model Fit Measures. AMOS Plugin. http://statwiki.gaskination.com/index.php?title=Plugins
Article history:
Received: 23.02.2021
Revised: 10.04 .2021
Accepted: 03.06.2021
Available online: 30.06 .2021 